Dishinikawshon Jesse: A Life Transformed

Jesse Adrian Thistle

Master's candidate, Department of History, University of Waterloo

aboriginal policy studies Vol. 5, no. 1, 2015, pp. 69-93

This article can be found at:

http://ejournals.library.ualberta.ca/index.php/aps/article/view/25278

ISSN: $1923-3299$

Article DOI: http://dx.doi.org/10.5663/aps.v5i1.25278

aboriginal policy studies is an online, peer-reviewed and multidisciplinary journal that publishes original, scholarly, and policy-relevant research on issues relevant to Métis, non-status Indians and urban Aboriginal people in Canada. For more information, please contact us at apsjournal@ualberta.ca or visit our website at www.nativestudies.ualberta.ca/research/aboriginal-policy-studies-aps. 


\section{Dishinikawshon Jesse: A Life Transformed}

Jesse Adrian Thistle

Master's candidate, Department of History, University of Waterloo

Abstract: As an aboriginal man amputated from my Michif clan at the age of three, I am, just by being, a rejected part in the Canadian "system." The system first attacked my family in 1869-70, then in 1885, and drove my kin into the hills as they sought respite from British imperial expansion and the nation-state project of Canada. For a century-and-a-half afterwards, Canada never gave us the chance to heal from the loss of our sovereignty, the loss of our kin groups, the loss of our economic agency, and the loss of our lands. Over time, and in conditions of extreme poverty, the fabric of my people stretched and tore, frayed and raveled, and by my generation it had dissolved altogether; a whole generation of my cousins and kin were subsequently let go into adoption. By 1979, many of us were broken parts without purpose in the Canadian system. Many of us drifted from one foster home to the next, and, when we became old enough, we gravitated to juvenile detention centres, adult jails and prisons, homeless shelters, mental health institutions, and long-term care facilities. I myself was a young man without identity, without mode or instruction; by age 21 I had become homeless and an addict, and was in and out of jail. Below you will find my dark and desperate voyage through "the machine," and my experience of gambling blindly to find my purpose; it is a bloody, gritty, and visceral account of what happened when the system tried to shove me, a square peg, into a round hole, and is a story of what happened when that square peg took back the agency that was stolen from my people in 1885.

My name is Jesse Thistle, and below you will find stories of my journey from homeless addict to the halls of academia. The stories are short vignettes of memories I have of things that happened to me in my quest for sobriety. They are written in flash recollections, as the trauma of addiction and homelessness makes my memories fractured, and I can only briefly engage with these graphic thoughts before they reinjure me. I have put a chronology alongside the stories to show the progression of my addiction; all the stories are true and deal with a very dark and lost time in my life. Before reading these bits of biography, please note that they are violent, graphic, and at times sad or pitiful. Take heart, however, in reading them, as in 2015, at York University, I posted the highest GPA in the faculty of Liberal Arts and Professional Studies, I have won almost every essay award possible in my undergrad and discipline, I am on my way to grad school at Waterloo with plans to do a $\mathrm{PhD}$, and I am seven years sober (and I have proof of all of these accomplishments if you need to see them). Please enjoy reading about the "wild west" years of my life, and, if you would like me to expand any story into a full chapter, pick whichever suits you and I will oblige you where possible.

aboriginal policy studies, vol. 5, no. 1, 2015 
One more thing: these are but a fraction of the stories I have, and I chose them at random; I have many more if you are interested in peering into the mind of a recoveringaddict-turned-academic.

\section{The Life and Death Throes of Addiction}

\section{Real Date: May, 2005}

\section{The Gucci Bag and Flip’s Gun}

Flip's ' 38 was pressed so hard into my forehead that for a week after our encounter the pinkish-purple muzzle imprint remained engraved between my eyes. It was the size of a lifesaver and was a stark reminder that he would've blown my head off if the cops hadn't have come.

"Who is this fool you brought here? I told you not to bring anyone to see me! You know better than that, Jesse; now he knows my face!!!"

Spit and angry breath hissed through Flip's clenched teeth as the hammer cocked into firing position.

“That-that's Checko ... he-he-he's m-my bo-boy ... c-c-come on, dog ... I-I-I’ve known you for ye-years ... wh-wha ..." The words stuttered out of my mouth, tears streaming down my cheeks.

Just then a cruiser rounded the corner. In an instant, Flip rammed his pistol into his belt, pointed his finger at me, mouthed something, and fled on foot down King Street towards the Dairy Queen.

He was gone before I could process what had happened.

"Man, I'm sorry, guy. I never thought your buddy would react like that. We only wanted to score some dope. What is his problem?" Checko's astonished words told me that he didn't really understand how close I had come to death.

\section{Hail Mary Pass ${ }^{1}$}

July 2006

The kingdom of heaven suffers violence and violent men take it by force Matthew 11:12

1 Originally published in Homelessness is Only One Piece of My Puzzle: Implications for Policy and Practice (2015). 
Dead silence screamed danger. The frenzied squeaks of prison-issued blue deck shoes on sealed cement confirmed it. That was, of course, followed by wet smacks, fast pops, loud cracks, and finally a dull thud. Whoever the guy was who lay crumpled and unresponsive on the range floor, he wasn't conscious. His legs were seized straight, quivering uncontrollably, and he had pissed and shit himself. Later, after the routine cell search and customary lock down, I heard that he had died en route to hospital. Apparently he stole a bag of chips from another inmate's canteen, but who really knew? Furthermore, who cared? This was prison justice; the thief got what he deserved according to us, and society-at least that's what I told myself to cope with the tragedy of this senseless act. All I knew was that I didn't know anything and I didn't see anything. I had only heard it. But I wouldn't even tell the guards that much. I had to survive, and you did that by keeping your mouth shut and turning your head. But why was this my last and best option? Why would I put myself in the midst of this horrible violence and filth? The answer was simple: I did it to save my leg and my life.

$* * * * *$

Being a homeless person, you're matter out of place. You're the grotesque, unwanted wildlife living in the urban-hinterland forests. Everyone stares at you, judges you, and tells you to get a fucking job. The social distance that separates you from civilization also separates you from your own humanity. I know. I've lived it. Like some by-gone nomadic hunter-gatherer, you're exposed to nature's elements, starvation, and disease. You're on an endless sojourn to nowhere, and when your already-precarious wanderings are complicated by serious injury, often you fade away and die, forgotten and alone.

I wasn't going out like that. I couldn't let it end that way.

$* * * * *$

When the doctor's assistant cut away the orange-and-black cast that surrounded my right shin and foot, she gasped. It smelled like Toronto during the summer garbage strike of 2009. Rotting meat and stale sweat filled the office. Her face told me the truth, even if she lied. "It looks all right. Excuse me one moment, Mr. Thistle ... I have to get Dr. Jones."

She rushed out in haste. My leg had been throbbing before I even came to the fracture clinic; my toes had turned bluish grey-green and the back of my cast was leaking a swampy crimson; I knew things were not good, so I rushed my post-surgery checkup ahead six days. It had been four weeks since I fell out of my brother's three-and-a-half-storey apartment window (a casualty of a drunken, drug-fuelled misadventure), and three weeks since the hospital had cast me out into the streets. My fall had shattered my right calcaneus (heel), destroyed my right upper ankle joint, broken my left scaphoid bone (wrist), and sprained my right wrist. The surgical team decided it best to leave the wrists exposed so I could walk 
in crutches after they fixed the much more serious problem of my compressed right heel and ankle. They made the right decision given my circumstances.

The lateral incision on the outside of my right foot was the typical way to fix my injury. Performed in a ninety degree cut, it rode six inches along the back of the ankle and heel and six along the side of the foot. It should have worked. But I couldn't listen to Dr. Jones when he said no smoking, drinking, or drugging. It's not like I didn't try to follow his orders; I did. I just couldn't quit-I was an addict. More importantly, I didn't have anywhere to live. Well, technically I did have a place to stay, my brother's, but it was full of cat shit and dog piss, and hadn't been cleaned properly in years. It was a veritable cesspool of microbes and bacteria. I wasn't there long. After my friend Alan stole the neighbour's vintage bicycle, my brother kicked me out, cast and all. Understandably, he had to do what he had to do. If he had kept me, he'd have been evicted by the landlord, and we both would've been homeless. When I look back now, I figure that's probably where I caught the infection that almost took my leg-and my life.

When the doctor and the nurse came in with masks on their faces, my stomach dropped. He had in his hand a tool to take the staples out, another one that looked like wire cutters, lots of gauze, a baby-blue kidney-shaped weeping tray, and some medical tape. When I finally got the courage to look down at my exposed leg I nearly fainted. The black pussfilled blood blister on the front of my ankle resembled a giant deformed pierogi. My foot and lower leg around the wound were swollen, green, red, and greyish-yellow. When Dr. Jones took the staples out, the edges of the skin peeled back, exposing fat, muscle, bone, and metallic hardware. The smell was horrid.

"Not good; not good at all," he remarked. "The surgery has been a complete failure. Your leg is infected and gangrene is setting in. I will clean it for now, cut away the necrotic skin, trim the bone, but you are at serious risk of losing your leg if you don't take care of yourself."

With that, Dr. Jones set to work. At first I could handle the discomfort of him cutting my dead and infected flesh, but when I felt his full weight on my leg and then the sharp, wet pop from his bone clipper, I bellowed in agony, tears streaming down my face. My field of vision narrowed to pinpoints and then everything went glacier-white. My hearing echoed and dulled; the voices of the doctor and nurse became distant, then inaudible. I was in shock. I vomited all over myself, then passed out.

When I woke up, my leg was again in a cast. I had on someone else's clothes and felt really weak, but I was clean. The nurse then came in and told me I was free to go, but I had to speak to Dr. Jones before I left. She had in hand a prescription for antibiotics and a suction pump machine to attach to my half-dead leg to improve circulation, as well as 
a schedule for an aftercare nurse who was to come and change my dressings twice a day. When I told the doctor I was staying at the shelter on Bond Street, his face turned sullen. He knew, like I did, that it was a shithole of a place to recover in. I was used to staying there, though. Off and on, I had been homeless for close to ten years before the drama with my leg, and I had always been able to hold my own on the streets and in the shelter system. But things weren't like before. Now I was wounded and helpless and I couldn't even walk, let alone defend myself.

It didn't matter. I couldn't stay at the hospital. Unfortunately for me and others in my situation, hospitals aren't in the business of letting people recover; they are in the business of making money. I guess the people who wrote the rules never figured that homeless people have crippling surgery too and need a safe place to recover or maybe they did and didn't care. Who knows? All I knew was I wasn't welcome to stay.

Frightened, I grabbed the pump and scrip and stoically hobbled out of there. The worried look on my face, however, gave me away, and told the cab driver I was scared and deeply concerned for my well-being. He didn't give a shit. He kicked me out halfway to my destination after he found out I didn't have the fare to pay for my ride.

The first night at Glaxtonbury House, the pump was gone. By the third and fourth nights, my prescription, just like the expensive medical equipment, had been stolen. A week into my stay, the infection was back. Not surprisingly, the nurse never came. When I had the pump, my meds, and my hope, I could at least see the light at the end of the tunnel; I could at least dream of keeping my leg and walking on my own again. After my stuff was stolen, I had nothing left. It was then that I totally gave up and turned to the two things that had always made me forget: drugs and alcohol. The personal needs allowance (PNA) I got every day at the shelter bought me my morning "wake and bake" hit of crack, which killed the pain in my infected leg just long enough for me to make my way to Shoppers Drug Mart where I would steal mouthwash and razors (You'd be surprised at how much crack you can get for a pack of stolen triple blade Gillettes, and how stupefied a bottle of mouthwash can make you). I became the Listerine Fiend when I drank that dental antiseptic, and Crackula when I smoked rock, but both personas were really just masks I put on to conceal myself from the reality of my rotting leg and my pitiful homelessness.

The other homeless people around me on the streets who knew me tried to help my situation the only way they could. Some gave me free tokes of crack when the pain was unbearable; others shared their liquor when they'd find me passed out in the gutter. And the outreach people who knew me always gave me extra bus tickets, cigarettes, and a clean pair of socks whenever they saw me. Privately though, after they left, I would break down and cry. I couldn't even wear both socks, and the cigarettes and bus tickets they gave me couldn't fix my leg. 
About a week had passed when I realized that I couldn't feel my toes anymore. They were cold and unresponsive; day by day, their greyish-blue hue had turned waxy black-I hadn't even noticed because I had been too busy feeling sorry for myself in my hazy oblivion. The toenails fell away at the slightest tug or bump, and the skin sloughed off whenever I scraped it with my finger. It was happening: My foot was dying, just like the doctor had said would happen. I again rushed myself to the hospital.

He looked furious. “Do you know how sick you've made yourself?” Dr. Jones yelled.

The nurse promptly rammed a thermometer in my ear. I was sick, I could feel it. My upper leg and torso felt like they were on fire, and my head had been spinning for over a week. Dr. Jones told me he didn't even have to cut the cast off; he could smell the damage I'd done to myself.

"Mr. Thistle, based on your condition during your past visit, and your condition today, I regret to inform you that we will have to amputate your leg. The infection is severe, and if it spreads to your brain or heart, it will kill you." His words thundered into my brain and made my heart sink.

I don't remember thinking anything, but I do remember the words, "Like fuck you are!!!” erupting from my mouth. They came from somewhere deep within me. They were a knee-jerk reaction to an impossible proposition.

Frantically I stumbled up, mounted my crutches, and see-sawed down the hospital hall, tossing myself out the back door. It was all automatic. Before I knew it, I was in the dorm room at Glaxtonbury House; I don't even recall how I got there. Not wasting any time, I packed what little donated clothes I owned into a plastic grocery bag, collected my PNA, and fled the premises.

The subway ride to Finch Station felt like an eternity. I clutched my Pyrex stem, loaded with pain-relieving crack, the whole way. These were narcotics I bought at the shelter with the horde of bus tickets I had gotten from the outreach workers and my \$3.75 PNA. I had about a fifty piece. I promised myself that I wouldn't smoke it until I got to Brampton. I needed to get as far away from the hospital and the thought of amputating my leg as I could. Brampton, being where I grew up, seemed a safe and logical choice in my desperate flight.

Hopping onto bus route 77 was easy. It was something that I used to do all the time when I travelled between Toronto and Brampton. Anyone can do it. All you have to do is tell the driver you're homeless and need to get to a shelter and they let you on every time. I had a cast; how could the guy have said no? At Bramalea City Centre the bus's suspension hissed as the driver lowered the bus down for me to get off onto the platform. I promptly did so and hurried to catch the number 1A to Four Corners in downtown Brampton. 
A funny thought entered my head as I coasted through my old neighbourhood. I remembered back to when I had done petty time in jail for shoplifting or for break-andenter or breach of probation. I remembered how in jail I ate three square meals a day, I had a place out of the elements, I had all the medication I could ask for, and a hot shower. I also remembered how I could rest, read, and get healthy. Moreover, it was the best rehab imaginable. I then asked myself, Why the fuck am I wandering in the desert like a wounded animal?

What I had to do became quite clear. If neither the hospital system nor the shelter system would help me, I logically had to force the jail system to do it. I had to use the system to my advantage; it was my only option. I knew the state couldn't let me lose my leg, not while I was incarcerated-it would make them look bad. And everyone knows that the government will spend billions not to look like fucking assholes. Besides, and sadly I thought, no one gives a shit about a homeless guy with a rotten leg, but they do care about a guy who is willing to do anything to survive. And everybody loves a guy who is willing to sacrifice himself by throwing a hail-Mary pass in the dying seconds of the game. I had my plan.

"Last stop!" the bus driver called out as we entered the downtown terminal. With that, I stepped off onto the platform and into relief. I lit my stem. The sizzle of the stone in the chamber gave way to a milky stream of smoke that cascaded down the back of my throat. The imaginary fire engine that howled in my ear rang with the intensity that only smoking crack cocaine can conjure. My pupils widened and my heart raced. I found myself bravely striding towards the Seven Eleven at Church and Main Streets, pursuing the goal I had hatched on the bus. I had never done anything like this before; never had I robbed someone, or even wanted to. But this was all 'way beyond me wanting to do it. I had to. My circumstances demanded it. The hospital system didn't want to take care of me; I cost them money. The shelter system couldn't take care of me; they weren't equipped to take care of homeless people recovering from major surgery. And I couldn't take care of me-I was a crack addict and alcoholic.

The leftover crumbs of crack resembled flecks of yellow glycerine soap that peppered the centre of my palm. With the tips of my fingers I packed the remaining shards of crack into my pipe and lit it. My leg had hurt slightly before, but with this last blast, the pain completely subsided. I was ready.

I gritted my teeth, steeled my will, opened the door, walked in, and robbed the convenience store-and in doing so, changed my life forever. 


\section{The Turning Point and Botching the Robbery}

\section{July, 2006}

\section{Robbing the 7-11}

Entering the convenience store, I was so scared. It's too late to turn back now, I thought, there's nowhere left to go. I swallowed hard and grabbed the first thing in sight-a submarine sandwich wrapped in foil and a small plastic jug of kitty litter. I brought both to the counter and waited until the clerk rang opened the register then made my move.

"Give me all your money or I'll kill you!" I yelled as I pointed the sandwich at the clerk, lettuce and mayo flying everywhere.

The guy looked at me with a perplexed half-smirk on his face. "Are you serious pal? Er ... wait ... um...?"

A long, awkward silence ensued, or at least it felt that way. Maybe only a second or two actually passed.

"Of course I'm serious! Give me the cash and hurry the fuck up!!!"

My falsetto voice faltered with nervous desperation, and although I looked totally ridiculous and unprofessional, he could see I meant business. I wasn't leaving without money.

"Look, cowboy, I only have \$90-store policy. You can take it; we're insured, so I really don't care. I just want to get home to my family. Understand?"

I understood clear enough. With that, he stepped aside and let me rob him. My jittery hand rifled through the till, firing change and dollar bills all over the place. I'm

sure I lost cash more than I grabbed. My other hand forced my weapon-sandwich through my fist like hamburger through a meat grinder.

Out of the corner of my eye I saw the teller on the phone with the cops. I scrambled and tried to bolt out the front door, but missed the handle and slammed head-first into the glass.

"Ahhhh!" I yelled as I clutched my head, dropping even more cash. The instant goose egg that formed made me dizzy and punished me for my frantic, cockeyed robbery. I almost passed out right there. 
"You won't get far with that cast on your leg," the clerk hollered as I rounded the back corner of the 711. "They're on their way right now, they'll get you soon enough!"

As soon as I was out of the teller's sight, I jumped into the store's dumpster and covered myself in juicy trash. I sat there as frozen as a statue for a good four hours until the police cruisers, helicopter, and dogs were gone. I was lucky, I guess. The garbage smell masked my scent from the dogs, and the police search quickly expanded away from the 711; they never even thought to look in the trash bin.

When the coast was clear, I emerged as smelly as a New York City rat and counted my take: \$37.20. That was all I got—that, and the giant bump in the centre of my forehead. The ironic thing was that I was trying to get busted so I could go to jail and get treatment for my infected leg. But I couldn't even do that right. I thought to myself, This has got to be the worst moment of my life.

\section{Sharing}

October, 2006

Lauriston, my cellmate, was a man of 70 from Bermuda. He said he was in for probation violation, but I was skeptical. People in on breach never get more than 30 days, and here he was on his way to the Pen with two years plus a day. I never wanted to press, but I always wondered about him, whether he was truthful. Had he committed some heinous crime? Or was he just what he said he was? You can never trust other inmates' words, especially if they're in protective custody.

I ended up in protective custody because I had a wide-open wound on my severely damaged foot. The gaping wound on the side of my right heel had just recently started to heal after my stay in the medical wing, where, with a strict regimen of antibiotics and a total lack of access to illegal narcotics, I finally got rid of the infection that almost took my leg. The screws (jail guards) felt I couldn't yet defend myself, so they put me on Block C in the PC wing where I could mend. I guess it was the safest place for me in my condition.

Besides deciding whether Lauriston was truthful, I also wondered how he had set up the sugar trade that made him wealthy in packaged sugars - a real commodity that could buy food and help make mash liquor from orange peels, water, and bread; along with tobacco and dope, mash was a top jail product that could buy friendship and allies as well as retribution.

Each inmate only got one sugar packet on his breakfast tray, one for lunch for our tea, and one for dinner, again for tea, but Lauriston had a constant pillowcase full of sugar packets, and he consumed at least five of them at each meal. 
At mealtimes, the sugars would just pour into our cell to from the other inmates like an endless procession of cargo brought to Lauriston by Bucky the quartermaster (the inmate who gives out and controls the food; this is the most powerful and respected position on the range).

"Here, Lauriston," said Bucky, "This is yours."

Lauriston reached both hands through the food-port and Bucky dropped a sock full of sugar packages into them.

“Thanks, Youngblood. Me 'ave sumtin fa' you. Hold up." Lauriston then reached down into his dinner tray and handed Bucky his potatoes.

Bucky smiled and thanked him for the carbs—-much-needed fuel, as Bucky worked out compulsively three hours a day.

"I got you, wisdom. Always."

Bucky dapped his fist on Lauriston's and continued distributing the rest of the trays to the other cells down the line.

"Ya see dat, Indian," Lauriston grinned over to me. "Give pon de nex' man and de nex' man prosper with you."

"It's a nice theory," I snapped, "but how do you know they won't just take your stuff?"

"What you tink'n, fool? Wake your rass up. We's people too, you know; we give and give, we trus' and trus', just like all dem out dere, all dem 'good' people. Know dis: All brethren who give to his brethren prosper by his brother, and all dem selfish bloodclaat that don't, get nuttin' but fire."

Lauriston was quite angry at this point. It looked like he was going to start swinging, offended that I didn't believe him outright. He kissed his teeth and muttered something, then turned to face me in a deadly serious manner:

"You see me? I'm an old man, I got no family, no drugs, no tobacco, no candy bars-I got nuttin'. But still my canteen ram with goodies and my belly full. Dem bwoy can take anytin' from me, but I know to give, even in dis place. And I trust dese guys and dey know it; some of dem never been trusted in dey whole lives. You know what dat's worth in Babylon?" 
"I'm sorry, Lauriston. I just ..." I scurried to the back wall to defend myself.

“Calm your rass, I'd never hit a cripple. Listen to me-I'm tryin' to help you. Try it. Give away your food and don' ask for nuttin'. Jus' give it; dat means a lot in here. Trust dose guys to be good people, jus' give it. But never give it to a bombaclot who tries to take it; if dat happens, then you beat his rass-life and death. You'll see."

I agreed to heed his advice and went to bed, all the while thinking about his pile of sugar.

The next morning when Bucky came around, I looked at my breakfast tray, remembering the lecture old Lauriston had given me the night before. I reached down, grabbed my cereal package and bag of milk, and handed it to Bucky.

“Here, take it," I said.

Bucky just looked at me and put the cereal and milk on his tray and continued on.

Nothing came back. I waited there for an hour, looking over at him while he played cards with the other quartermaster, Priest. He didn't so much as glance up at me.

"What a prick." I thought. I sat dejected in my cell for the rest of the day.

At lockout, I walked over to the shower like I was supposed to do, took off my overalls, and was about to get into the stall when Bucky came up to me with Priest and grabbed me.

"What the fuck, you crazy, star?" he said. "You gon' wash your dirty rass in my shower? You never wash your dutty self, star."

Bucky was right, I never showered. I was afraid of getting an infection in my foot as much as I was afraid of getting raped. They were fears that kept me from the showers on a daily basis, which in turn kept me perpetually dirty and stinky. My face turned white at the thought of being beaten, even raped, by Bucky and Priest. I closed my eyes and wished it would end quickly.

"You can't go in there, bomba. Open your eyes. Open dem and look at me!" Bucky yelled. But, frozen with fear, my eyes remained glued shut, my body stiff as a board. Bucky shouted again, only louder this time. 
"Open your bloodclaat eyes, star. You can't go in dere. Not with your foot wound open like that. You'll get an infection. Here," Bucky said.

I felt something squishy press against my chest.

When I opened my eyes and looked down I saw Bucky was giving me his black prison sandals.

"You need to wear dese to keep your feet off the ground. The bacteria is on the ground; if you step on it, it will get in your wound and you'll lose your foot."

As soon as Bucky said that, Priest grabbed my shoulder and added, "Turn dem over. Look. I carved de Star of David on de bottom to protect you against de filth of dis place. One, bless."

There it was, the Star of David, engraved right on the heel, right where my injured foot would rest.

“Th-th-thanks ...” I stuttered.

Priest and Bucky just smiled and returned to their card game, leaving me flabbergasted and grateful that I didn't get the "dry hammer." They didn't say anything or even acknowledge that they'd heard my thanks; they just let me shower in peace.

$* * * * *$

When I returned to my cell, Lauriston was there, waiting. I told him what had happened. He just grinned and said "I told you so." He then encouraged me to keep giving and trusting at every meal, whenever I could. I followed his advice and I gave as much food as I could, and sure enough, soon I too had all the food I could eat, all the sugar I wanted, and all the juice crystals I desired. Moreover, I had all the respect one could hope for inside.

The abundance of food I ate in that cell helped to heal up my foot, and in time, when Bucky and Priest were moved on to Lyndsay Supermax, I took one of their jobs as quartermaster because the guys on the range knew I was fair and that I'd share, just like Lauriston taught me to do.

I have continued to share and expect nothing since my time inside and Lauriston was right: when you give, you get, and you always get more than you give. It is as simple as that, and just like he said: "All people who give to dose around dem prosper by dem, and all dem selfish bloodclots that don't, get nuttin' but fire."

I just wish I hadn't had to go to jail to figure that out. 


\section{Remembering on a Winter's Night}

February 2008

I remember on that frigid January night you told me that if I fell asleep outside, I wouldn't survive.

That I'd freeze before morning because I wasn't dressed for the weather and it was thirty below.

I remember I just didn't care as I closed my eyes, hoping to end it all.

I remember how resolute and bitter I was towards the world and that I had every intention of sleeping forever on that cold, cold night.

But I also remember awakening sometime later with you brushing the layers of snow off my frozen face, and you stubbornly refusing to leave my side until I got up.

Whoever you were, I want to thank you for saving my life and for helping me believe in the goodness of people again.

I'll always remember the lesson you taught me.

I'll never forget.

\section{Salvation and the Soup Kitchen Lady}

February, 2008

"Hey, you!" she called up to me, "get down from there."

I paid her no heed on my ascent to the summit of the half-completed condo tower on Rideau Street.

"I said get down, or I'll call the cops."

My boney hand grasped the edge of the roughly finished concrete ledge as I hoisted myself up and continued to ignore her.

My muscles may have atrophied from addiction and soup kitchen slop, but I was still as spry as Golem of Middle Earth looking for his precious, my arms and legs as ropey and sinewy as a marathon runner in mid-schedule training. 
"What do you care?" I shot back. "You don't know me. Beat it."

Why do all these do-gooders keep fucking with me? I muttered in my head, Why can't they just mind their own Goddamned business? I could feel her eyes drilling into my back as I pulled myself up another floor.

"I work over at the Sheps. I've seen you on the breadlines." The pitch of her voice raised the higher I went.

"Yeah,” I replied without looking down, “so what?"

Her efforts were useless. I had my plan all worked out in jail. After I got released, I was to climb to the top of the luxury tower, close my eyes, spread my wings, and float away from my horrible existence.

I had had enough. The streets and jail had ground me down to a pitiful nub of a soul; eleven years of the life will drive anyone nuts, will drive anyone to suicide. And shuffling around like a homeless rat on cocaine was bad enough-but jail-? That was the worst. Whenever I got arrested I had to go into protective custody because I got beat up everywhere I ended up 'cause I was an emaciated wimp. Moreover, no one would ever take my callsnot family, not friends. It always bothered me that rapists and murders had their calls taken but when I, a petty thief and addict, tried reaching out, all I got was dial tones, slammed receivers, or answering machines. And letters-forget about it. I'd wait every day at the front of the range for word from the outside world, and every day I was disappointed, except for that one time when Jessica wrote me a Dear John letter to tell me she was moving on. She at least acknowledged I was alive; I can't say the same of the rest of them. All in all, I was sick of being forgotten. lev-"

"Listen, lady, I'm just going to go to sleep up here 'cause it's safer here than on ground

She cut me off before the lie left my lips. "Oh yeah?" she said, fumbling for words. "Well, it's the middle of February, and it's cold as hell. You'll freeze up there."

Just then the winter wind bit through my donated H \& M hoodie, reminding me of my mortality. I felt weak all of a sudden.

“Listen, can you please just leave me be?” I pleaded, "I just want to be left alone."

"I don't believe you," she fired back. 
Not wanting to lose my nerve, I quickened my pace and reached for the next floor before reality set in. In my haste, my hand slipped on some run-off ice and I lost my grip. I fell onto my back on the floor below, the wind completely knocked out of me. Writhing in pain, I almost rolled off the edge to my death. My heart raced at the thought of falling backwards six storeys.

"You almost got what you came for!" she shouted.

Gasping for air, I curled into a ball and covered my ears, trying to hide from her incessant voice and what had just happened; icy tears inched down the bridge of my nose.

"Hey, you know what? I do think I know you. You told me about your grandma and your brother Jerry and how they'd call you in rehab. You said your name was Jesse or something like that."

The sound of my own name dropped on my frozen heart like a sledgehammer as the sweet faces of my grandmother and brother welled up from somewhere deep within my memory-it was a twin feeling that both shattered and warmed me at once. I hadn't heard my own name or thought of my bro or grandma in weeks; they, the only two people who ever looked out for me when I was in trouble, had found me yet again, up there on that building. I missed them both so much at that moment.

The woman down below was right; I did know her. She was the woman who fed the guys down on King Edward Avenue every Thursday at the Sheps, and I did tell her about Jerry and Grandma and how both would check up on me at Harvest House.

"Yeah, and you said you missed them and wanted to make them proud but hadn't spoken with them since you left rehab. I remember."

I couldn't take it anymore. I wanted some kind of human interaction. I collected my pride, rolled over, and peeked over the ledge to see if I could recognize her. Sure enough, there she was, black hair hanging behind her back as she looked up to me, her big smile beaming like the afternoon sun on a summer day.

“Come on now, enough of this nonsense. Let's get you some soup and socks."

"I'd like that more than you know," I squeaked. I picked myself up and began my long descent into warmth.

When I got to the bottom, she greeted me with a brisk hug and said, "That was close."

"It sure was," I replied. 
As I looked at her I was thankful she found and remembered me, and I was also thankful she reminded me of my bro and my grandma.

\section{Homeless at the Bus Stop}

May 2008

Saving My Humanity

Good Stranger: "Hey you. Buddy. Come here."

Me: "Me?"

Good Stranger: "Yeah you (points to me). Every day I watch you out here shuffling around begging for money at the bus stop and you're always limping on your right side, what's wrong with your leg?"

Me: "Oh that, I fell off a building and shattered my leg-they rebuilt everything with surgery and screws, but it was a failure and got really infected. It hasn't really healed yet. It's hard to heal when you're homeless."

Good Stranger: "That sounds really serious ... So can you work? I mean, you can barely walk upright."

Me: "Not really, but not because of my leg. I'm an addict, I can't hold down a job-I just can't do it. I get my cheque and then ... well ... you know ... That's why you see me out here begging. I get dope sick in the morning."

Good Stranger: "Huh ... bummer. Hey listen, just so you know, I'm a foot doctor, I work right down on Rideau Street, and your leg and posture don't look good-let me buy you a pair of new shoes, it's the least I can do. I think it will help your foot. I hate seeing you limp around like this every day."

Me: "You know what mister, I can't. You're such a nice person; you've taken the time to talk to me looking like this (I point to my tattered clothes and my unwashed body). I must smell horrible to you, nobody ever talks with me these days, I don't blame them ... So, because you're such a nice person, I don't want to take your shoes 'cause I'll just sell them and buy dope."

Good Stranger: "You can do whatever you want with them, they'd be yours to do whatever-"

Me: "I just can't take your shoes, I'd feel horrible, I can't trust myself you don't understand. I don't have much humanity left in me. If I sold your shoes something within me would die, something crucial. I just can't do it." 
Good Stranger: "Well let me buy you something to eat then, we can have a late breakfast. Come on."

Me: "Sure, that would be nice; I haven't eaten in a while. Sorry about the shoes, I hope you're not offended."

Good Stranger: "Never. Don't be foolish. Hey, I hear the Olephant makes a mean bacon and eggs ..."

Me: “Oh yeah.” My stomach starts to rumble uncontrollably.

\section{In Drug and Alcohol Rehab \\ Running on Glass}

July 2008

The laces on my blue Asics were discoloured and frayed at the ends, evidence of previous ownership, but I didn't mind. They were brand-spanking-new to me, and I loved them for what they were-a second chance-even if I was petrified to use my mangled foot again.

Harvest House always got these kinds of leftover donated running shoes from the local Running Room; the hookup was one of HH's executive member Gary Wand's connections, and all the guys from jail got them when they came to rehab from the clink. Some guys mocked the shoes; those guys always relapsed and ended up back in the can within weeks; but others, like me, appreciated them, and seemed to last a little longer in sobriety-two or three months. But they too always seemed to go back eventually. It's bloody hopeless, everyone fails, I thought as I admired my kicks.

Gary Wand was a recovering addict like us jailbirds, and understood well the value of running as addiction and recidivism therapy. He had used it himself to get sober and out of trouble some fifteen years earlier when he washed up on the front lawn of Harvest House from Montreal, a wounded and broken addict. Everyone at the centre always said that back in the day Gary was worse off than all of us, and his entry photo, taken the day he arrived at Harvest House, confirmed it. He did look like a real bag of shit then.

If Wando can do it, I can do it, I said to myself as I hobbled to the starting line of the daily $5 \mathrm{~km}$ jog. The reality of my foot, however, quickly snuffed out any newfound courage I had, replacing it with doubt and apprehension.

"Gary, I'm scared, I ..." I pleaded as the pack began running and pulled out ahead of me. "I don't know if the pins and screws in my foot will hold. It's only been about four months 
since it healed, and ..." The grinding of pebbles under the departing runners' shoes muffled my voice. I waddled to catch up and make myself heard. I looked like a crippled penguin shuffling against the wind on a sheet of ice-I was going nowhere fast.

Gary looked back and smiled. "Just go slow, trust me." He turned his head and joined the other runners.

"Go slow-are you fucking kidding me?" I shot back with venom. I received no response. "Fuck you!" I yelled.

It was no use; Gary couldn't hear me. He and the others had already rounded the corner and gone down the hill. They had left me to face my fear alone.

When I looked down at my feet, they looked funny. My damaged foot was longer than my good one, a consequence of the reconstruction surgery, and the atrophied leg it was attached to resembled a sad, dollar-store broomstick-the hollow metal kind that bends if you sweep too hard. I wonder if my leg will bend and break if I run? I pondered. Better that than my foot falling apart. I laughed out loud at the thought of either gruesome scenario, tears of hopeless defeat running down my cheeks. I'm fucked both ways.

My fatalist attitude angered me and made me think of my grandfather Thistle-the man I fought with my whole adult life, the man that would never let me quit, even when my hands and heart couldn't go on. It had been a long time since I'd thought of the old man, but as I did, he was there, on the side of the road in my head, kicking my ass again like he always did when I was growing up.

“Get going," I heard his gruff voice bark. "Get going, and stop feeling sorry fer yerself."

Just then something astonishing happened, something I had no control over: all of a sudden I let go and I just ran. Like an infant that takes its first steps, I didn't think about it; I just put one foot in front of the other, leaned forward, and went-I ran.

My skinny leg and canoe-shaped Franken-foot tilted and slipped on the roadside stones; they buckled and shook and wobbled, but they held. They had no power whatsoever, and operated like a pivot, like a pirate's peg-leg. My toes didn't do much at all either, and I had no push or spring to my gait, but together everything worked! Somehow my leg and foot worked!

The pain that shot up from my ankle to my brain burned, the consequence of bone and gristle grinding on wires and metal, but it was bearable. And the bottom of my foot felt like I was running on broken glass, the pressure from running as foreign to it as weightlifting is to a freshly uncasted broken arm. Is this how it feels for babies to walk? I wondered. 
As soon as that thought ran through my head, my stick leg gave out, and I tumbled down onto my face into a cloud of dust and pebbles. The dirt in my mouth tasted glorious.

"Holy Christ, I did it!" I exclaimed in a voice filled with amazement and joy, blood dribbling down my upper lip from my nose. I wiped my face and looked to see if my foot and leg were all right; they seemed to smile back at me as I scanned their surface and examined them, assuring me that they were fine and that I could trust them once again ...

\section{Saying Goodbye to Grandma}

\section{February 2009}

It was 9:30 pm and I was passed out, exhausted from my daily kitchen responsibilities at the rehab center.

"Hey Thistler ... Get out of bed, you have a phone call!"

I barely heard Rob's voice when he yelled for me a second time.

"Dude, get up! It sounds important. It's your grandma in Toronto, get up!"

Rob was always the type to be joking, or laughing, or horsing around, never serious. So I knew what this meant. I jumped out of bed and ran to the phone.

"Jesse ..." whispered the thin voice of my grandmother, the woman who raised me. "It's my time. I need to see you. I'm in room 525 at William Osler, come see me."

I hadn't seen my grandmother in over four years. I had been locked up for more than half that time, and the remainder was spent wandering around, getting high, committing crimes for pocket change.

"But what about Grandpa? I can't go if he's there."

"Never mind him!" she said with mustered resolve. "Just come. Don't worry about him-he'll come around some day, you watch, you'll both make up, I'm sure of it. He really does love you, you know."

She was right. Grandpa and I did love each other; we just never get along after I betrayed him and made him watch as I pissed my promising young life down the drain, then smoked the rest of it in a crack pipe. Regardless of the lies I told myself, the truth was he resented me because he saw so much wasted good in me. 
"I love you grandma. As soon as I get my day pass, I'll be there."

"I know, Jesse."

By the end of the day I was in a moving truck on my way to see my grandmother. Harvest House heard what was going on, and immediately found a way for me to go and see her before she died.

I knew I would never get clean and sober long-term if I didn't get to say goodbye in the right way. I just had to be there.

Two weeks after she kissed my cheek in the hospital, she was gone; she hadn't even seen me graduate from rehab, nor did she ever know me as a sober person in my adulthood, a fact that haunts me to this day. During our last embrace she hugged me tight, then, as we let go, she pushed me away. Her burst of strength surprised me; it was as if she were saying, Go on, boy, make your way in the world. Make me proud, I believe in you.

I'll always remember that slight shove and what it meant.

\section{The Process}

\section{March 2009}

I didn't get it right the first time. No one ever does.

Four months into treatment, and dreams of liquor and narcotics had driven me over the fence with my buddy Max into the pitch-black February night.

I was in no shape to face old man winter in Ottawa; I didn't even own a jacket or sweater, and my pants were torn open by my leap to freedom, my balls blowing in the frozen winter wind.

I didn't care. All that mattered was that I was free and that I was going to be high and drunk and that I didn't have to listen to Bill yell at me in group therapy or read the King James Bible while feeling sorry for myself, begging God for a forgiveness I knew I didn't deserve.

"Fuck it, tonight is mine," I proclaimed. "I'll most likely get arrested anyways. I'm going on a tear until my cash runs out and the police catch up with me. I'm going out in a blaze of glory!" 
Max grinned a demonic grin and let out a hellish AC/DC scream, complete with heavy metal devil-horns thrust into the air.

When we arrived at the Mission, we immediately scored some dope and divided it between us. After the first blast of rock, Max met up with an old working girl he dated before his stint in rehab, waved to me, and together they disappeared around the corner. I heard some time later he ended up in the pen for something really serious. I don't recall for what, but he was one crazy guy.

Four weeks later, after one hell of a bender and a series of sloppy shoplifting and petty crime interludes, I was picked up as a fugitive of the law in front of the Shepherds of Good Hope. They shipped me to OCDC where I once again found myself heckling the screws and counting the days and cinderblocks.

I hated the monotony of doing time, and those institutional bricks. They seemed to follow me wherever I went-jails, mental institutions, probation offices, hospitals, detox centers, detention centers, shelters, the Sally Anne, welfare offices, court holding cells, police station bullpens-everywhere. If I was sick of anything, it was seeing those institutional 16-by-8s.

I once counted 182 of them in my cell at the Don Jail, 197 at Maplehurst, and 165 at OCDC. But Harvest House Rehab center, it had 368 cinder blocks per dorm room; and that made HH look like the Ritz Carleton to me.

When I called $\mathrm{HH}$ to vouch for me in court and bail me out, Charles Ledoux picked up the phone.

"Have you had enough of the 'life, of the Stone Age, Thistler?"

He was always such a smug asshole.

"Come get me outta here!" I begged. "I'm sick of it all and I'm especially sick of this jail food-reminds me of crappy retirement scraps they feed old people."

He laughed. "What, you don't like steamed dog food?"

Eleven days later, Grant from HH came and bailed me out and I was back in rehab, shaking and vomiting and wishing I would die.

But yet again, in the desperate throws of wretched withdrawal, I scrambled over the fence under cover of night, seeking respite from my demons; soon after, I was arrested again. 
I must have jumped that fence in the back, gone through the system, and been bailed out four or five times before I finally got it right.

Looking back, I don't feel sorry for myself for failing all those times, because that is the nature of sobriety. It's ugly, it hurts, it's full of failures, setbacks, disappointments, and it usually doesn't happen the first time one attempts it. It takes multiple efforts, dogged stubbornness, a lot of luck, support, and above all a good program and a loving community. And if you want it badly enough, one day you will get it right. You just have to keep in mind one thing: sobriety is a process, not a destination.

Oh, one more thing: the craziest thing about my recovery process is that I could have walked out the front door of $\mathrm{HH}$ at any time, but in my delusions and paranoia, I chose to jump the back or side fence. All these years later, I'm still trying to figure out what I was thinking or why I did that ...

\section{Bravery}

\section{Released from rehab July 15, 2009; date of memory July 19, 2009.}

The most afraid I was in my whole life was when I apologized to my grandfather Thistle right before he passed. The old man was as tough as nails and didn't tolerate bullshit or people not living their truth. I was guilty of both in spades.

I remember walking up to his room in the oncology ward at William Osler Hospital thinking of what I was going to say, my hands sweaty and heart trembling uncontrollably. I squeezed Lucie's hand like a vice grip; she smiled back and tried her best to comfort me.

The old man and I hadn't talked for fifteen years because I had been such a knucklehead; my behaviour forced him to shut me out. I was a hazard to the family and myself. I left him with little choice.

When I entered his room, my Aunt Sherry was beside him, holding his hand, tears streaming down her face. She whispered to him and he looked up to me. I had no words, neither did he; we both just looked at each other and wept.

After some time I worked up the simple words "I'm sorry, Grandpa ..."

"I know, Jesse," he said. "It's okay." He held his arms out and we hugged.

That was the bravest moment of my life, and probably will remain so for the rest of my days. 


\section{The Suit}

\section{August 2009 and January 2015}

When I got out of jail and rehab, I wore a cheap suit every day. I would slick back my hair, shine my shoes, press my shirts and pants, and tie my tie in a big Windsor knot like it was my religion. Yes, every time I left the house I dressed like that, and did so for a good month straight until my Uncle Dave told me to cool it on the suit. You see, I was trying to show the world my worth with a tube of gel and a late-1990s ill-fitting donated suit. It was my way of proving I was worth a second chance.

Today on the way home on the bus, I saw a guy like that: he was fresh out of jail and had a cheap suit on, just like I used to wear. He was rough around the edges-prison tattoo peeking out from his collar, cheeks and eye sockets filling in from past addictions, and his knuckles rough from holding his ground inside. In that moment, I turned my head and said a prayer for him and asked God to help him find his way.

\section{Abdi: the King of Somalia \\ January 2005 and April 2015}

"Goodnight Abdi, you crusty old bastard," I said as I rested my head on my pillow.

Abdi was my buddy who'd always sleep in the bed next to me at the homeless shelter. I always liked joking with Abdi to get him going, and hed always do the same with me. It was our only form of entertainment in this hospitable yet horrible place.

"Hey, I've been meaning to ask you," I said, "remember when you said you were the King of Somalia? Well ... is it true?"

My question was a direct attack on Abdi's royal pedigree, and was sure to get a reaction. As expected, his face became flushed with anger and his eyes bulged out of his head.

"Would I lie, peasant? Of course I am the King of Somalia! How dare you question my royal blood?!"

Abdi was a Somali man of about 65, and I of course knew he wasn't Somali royalty. Life had not been good to him. From what I knew of him, he'd fled Somalia with his family when civil war broke out in the country back in the early '90s. Soon after, he developed into an alcoholic, and his wife left him for another man. Abdi would reminisce about his homeland, telling me of how he used to shepherd massive herds of cattle on foot between Kenya and Somalia and how he'd sit every night watching the orange-red African sunset. 
It was something he had done since boyhood, and by the way his eyes lit up whenever he talked about it, I could see it was something he loved and missed dearly. I tried to imagine how hard it must have been for him to be forced out of his life by the perpetual civil strife in his beautiful homeland, only to end up in a homeless shelter in a foreign country that seemingly didn't want him, or his alcohol problem.

"Hey Thistle," King Abdi said as he leaned over with an intense look on his face, "you know how I know you're a real streeter like me?"

The sour booze smell on his breath demanded my attention.

"No ... no I don't. Maybe it's the way I drink the last of the piss-water from the Old English bottle?"

He cringed, imagining the taste.

"No, that's just disgusting-dirty Canadian drinking dirty American beer. No, young blood, it's in the way you sleep. Look at you." He pointed at my covers.

“How do you mean?” I asked. "And why are you watching me while I sleep?"

"I always watch out for you when you sleep, to make sure no one steals your stuff."

Abdi was right; he watched out for me, and I watched out for him. It was just what friends did in this place.

"No, Thistle, it's in the way you sleep. You've had your shoes stolen so many times, you sleep with them on. That's how I can tell you're a real streeter. You're just like me, see."

Abdi then pulled up his blanket and exposed his grungy, mud-covered black boots. The smile on his face was priceless. "Only real streeters sleep with their boots on."

I looked around the shelter at the other guys' feet to see if they had their boots on in bed. Only about a third of us did.

"You see those young guys," Abdi said, pointing at the guys with their shoes off, placed under their cots, "they're little puppies, they aren't like us. They aren't real streeters; they're just down on their luck momentarily. One day, if they're at it long enough, they'll learn like we did: Never take your shoes off." 
Abdi was right. I never noticed that about myself. I had been homeless so long that I always went to bed paranoid, with my shoes on. So many times in the past I had had my boots stolen while I slept in shelters that before bed every night I tied my shoes on with triple, even quadruple knots just to give myself a chance of keeping thieves from stealing my shoes right off of my feet. And even then, sometimes they got them off. Having no shoes and being homeless was the worst; often it would take a day or two to find a new pair from the donation box that fit. And that was if you were lucky. Sometimes you'd have to leave the shelter at 7 am shoeless and wait for the chaplain's office to open at $8 \mathrm{am}$, in order to get a voucher to take to the Sally Anne up the street where they might outfit you with a new pair. Other times you had to go without for a few days, or steal a new pair from Zellers and risk your freedom. When it happened in the winter, it was almost unbearable.

"Yeah, I guess I do sleep with my shoes on, eh buddy?" I laughed at the pitifulness of the thought of how normal it had become for me to go to sleep all laced up.

When I first got sober at Harvest House, years after my conversation with King Abdi in the shelter, I still wore my shoes to bed, until one day a friend of mine noticed what I was doing.

"I used to do that," he said. "I won't steal your shoes, I promise. You don't have to live like that anymore." He smiled and showed me his shoes beside his bed. "See, I have mine right here; no one's gonna take them here, we're good people."

Apprehensively, I sat up, unlaced my shoes, then placed my boots beside my bed and went to sleep.

It's been nearly seven years since I took my shoes off that day in Harvest House rehab. Sometimes, when I get really stressed or feel afraid or out of control, I still get an urge to go to bed with my shoes on. But when that urge comes, I fight it, and I'm always successful. And, despite the terrible reminder of my past, I feel happy, because it makes me think of that conversation in the shelter all those years ago. It makes me think of my old friendAbdi, the King of Somalia. 